\title{
DGF Note
}

(t)

\{ 50,5$\}$

Bulletin of the Geological Society of Denmark

Vol. 44, p. 187-188. Copenhagen, 1998-()2-28

https://doi.org/I().3757(0/bgsd-1998-44-13

\section{Late Holocene deflation of beach deposits, Skagen Odde, Denmark}

\author{
LARS B. CLEMMENSEN \& CHRISTIAN ANDERSEN
}

Skagen Odde is one of the largest spits in the world. Its growth began around 7())() BP after the culmination of the Early Atlantic transgression (Petersen 1991). and the spit has now reached a length of more than 30 $\mathrm{km}$. Owing to regional isostatic rebound, the southernmost and initial part of the spit strandline deposits now occurs up to $13 \mathrm{~m}$ above sea level (Petersen 1991. Hauerbach 1992). The west coast of Skagen Odde is presently receding and after strong storms excellent sections of the spit deposits are available. These sections indicate that the spit deposits are composed of: marine mud (base), sandy and gravelly shoreface and beach deposits, peat (the so-called Martørv, cf. Petersen 1991), and aeolian deposits (top).

Hauerbach (1992) noted the occurrence of a rather continuous stone horizon in cliff sections at the west

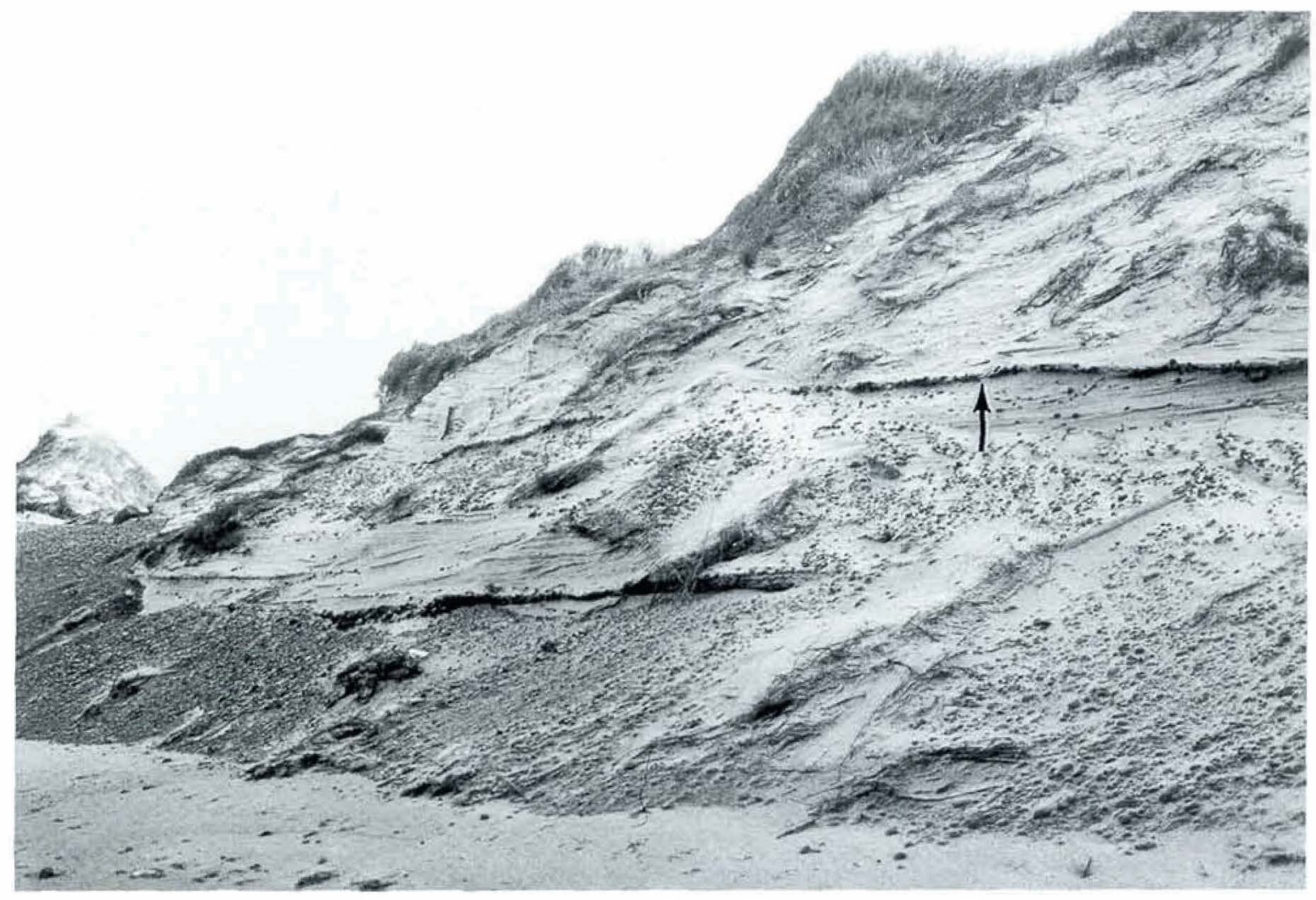

Fig. I. Section of spit deposits, coastal cliff south of Hejen, Skagen Odde. Note the prominent stone horizon (arrow) that separates lowermost shoreface and beach deposits of pebbly sand and gravel from uppermost dune deposits of wellsorted sand. The stone horizon is interpreted as a deflation lag and most likely formed during the Little Ice Age, when severe wind erosion and sand drift took place. Part of the deflation plain, which can be seen to the Jeft. was Jater overlain by dunes. The stone horizon occurs c. $5 \mathrm{~m}$ above sea level. 


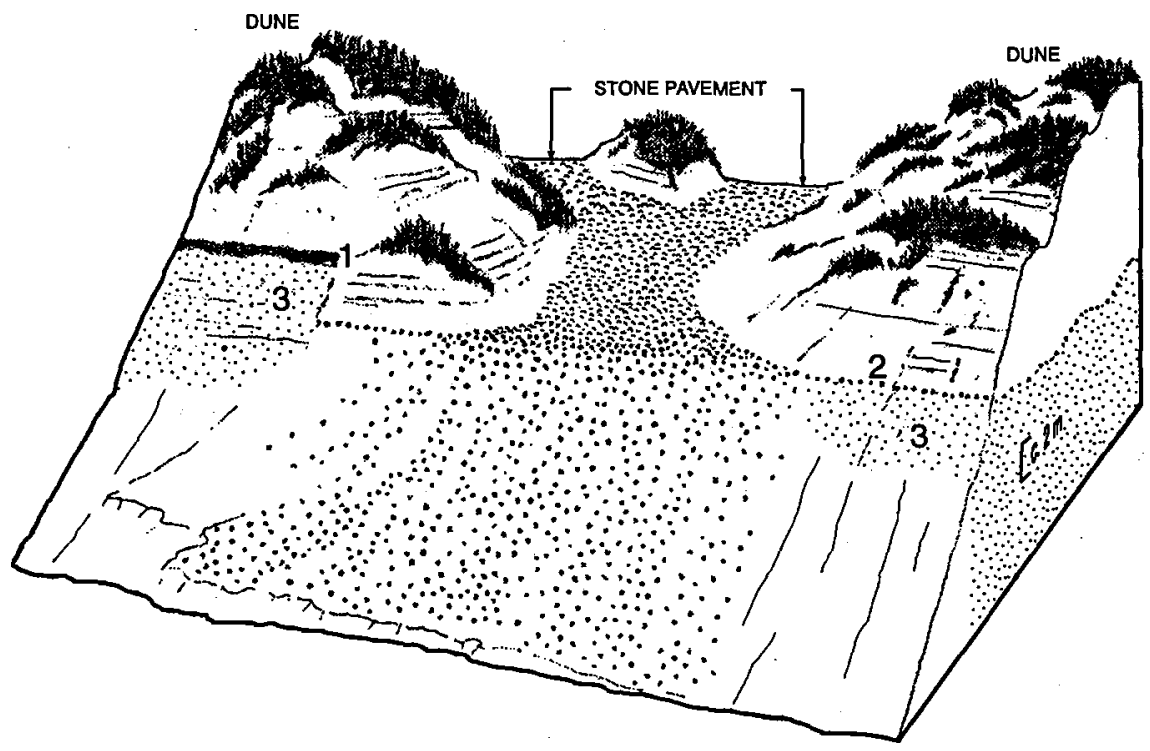

Fig. 2. Generalized coastal morphology and spit stratigraphy, coastal cliff north of Kandestederne, Skagen Odde. Beach and shoreface deposits overlain by the Martørv are laterally replaced by wind-eroded marine deposits capped by a deflation lag (stone pavement). Dunes locally overlie the stone pavement. 1: Martørv, 2: Deflation lag, 3: Beach and shoreface sand with scattered pebbles.

coast of Skagen Odde. This horizon was interpreted as a storm-generated beach and closely associated stone flat deposit, and the elevation of the raised stone horizon was therefore used to calculate the amount of isostatic rebound during spit formation (cf. Petersen 1991, Hauerbach 1992) and to construct a Holocene water depth curve for the area (Conradsen \& HeierNielsen 1995).

In connection with reconnaissance field work on Skagen Odde in 1996 and 1997 several stone layers in the cliff sections were observed. The uppermost stone layer is very prominent (Fig. 1) and should in most cases be viewed as a wind-formed lag deposit (cf. Jessen 1899). This stone horizon is flat to weakly undulatory; it is composed of rather closely packed stones of pebble and cobble size and has a typical thickness of 5 to $10 \mathrm{~cm}$. The stones, however, frequently cover most of the underlying slope giving the false impression that the stone layer is much thicker. The stone horizon is directly associated with wind gaps or larger deflation plains in the overlying aeolian landscape (Fig. 1). The largest of these wind-formed plains forms Råbjerg Stene. The stone covered surfaces of these plains have all the characteristics of classic windformed stone pavements. In cliff sections the stone layer typically disappears at the margins of the wind gaps, and it is replaced laterally by pebbly beach sand overlain by the Martørv (Fig. 2). At many places, however, the wind gaps are partly filled with modern dunes (Figs 1-2). The upper level of the sandy beach deposits is up to 2-3 m higher than the level of the laterally adjacent stone horizon (Fig. 2). This shift between well-preserved beach successions and winderoded beach successions is repeated in the cliff exposures. The true maximum height of the raised beach deposits can only be measured at places where the peat layer occurs (Fig. 2). If data are used from locations with eroded beach deposits, inferred beach levels will be too low. It is suggested that the deflation of the beach sediments and the formation of the stone pavements primarily took place in connection with the disastrous aeolian sand drift during the Little Ice Age (c. 1350-1900 AD).

The sedimentologic observations indicate that the upper part of raised beach deposits may be removed by deflation until a protective stone pavement has formed. Great care should therefore be taken to examine the possible effects of aeolian processes when the elevation of former beach deposits is used to establish Holocene isostacy and sea-level variation.

Acknowledgments. - Svante Björck, Karen Luise Knudsen, Gunver Pedersen and Lars Seidler provided helpful comments on the manuscript.

\section{References}

Conradsen \& Heier-Nielsen, S. 1995: Holocene paleoceanography and paleoenvironments of the SkagerrakKattegat, Scandinavia. Paleoceanography 10, 801-813.

Hauerbach, P. 1992: Skagen Odde-Skaw spit - an area of land created between two seas. Folia Geographica Danica 20,119 pp.

Jessen, A. 1899: Beskrivelse til geologisk kort over Danmark. Kortbladene Skagen, Hirtshals, Frederikshavn, Hjørring og L $\varnothing k$ ken. Danmarks Geologiske Unders $\emptyset$ gelse, I. Række Nr. 3, 368 pp.

Petersen, K.S. 1991: Holocene coastal and faunal development of the Skagen Odde, Northern Jutland, Denmark. Quaternary International 9, 53-60.

Lars B. Clemmensen [larsc@geo.geol.ku.dk] \& Christian Andersen, Geological Institute, Øster Voldgade 10, DK-1350 Copenhagen, Denmark. 27 Janua$r y, 1998$. 